\title{
The Reception of Paracelsianism in early modern Lutheran Denmark: from Peter Severinus, the Dane, to Ole Worm
}

\author{
OLE PETER GRELL*
}

Retrospectively, the appointment in 1571 of the two Paracelsian physicians, Peter Severinus (1540-1602) and Johannes Philip Pratensis (1543-1576), as royal physician to King Frederik II of Denmark-Norway and professor of medicine at the University of Copenhagen respectively, can be seen to have marked not only the introduction of Paracelsianism, but also the start of the medical renaissance in Denmark.

The importance of Peter Severinus and his work Idea medicina philosophica (Basle, 1571) in making Paracelsus's ideas acceptable within the scholarly community of early modern Europe was widely recognized by contemporary admirers, as well as antagonists. Since contemporaries labelled Paracelsus the Luther of medicine, it is tempting to widen the analogy and see Severinus as Melanchthon to Paracelsus's Luther. Like Melanchthon, Severinus eased and modified his mentor's ideas, thereby making them acceptable within the political and scholarly world where hitherto they had lacked appeal. Thus, the Heidelberg-based physician and theologian Thomas Erastus recommended Severinus's book as the most palatable face of Paracelsianism as early as $1579,{ }^{1}$ while another influential critic, the Wittenberg professor of medicine, Daniel Sennert, in his book, De chymicorum cum Aristotelicis et Galenicis consensu ac dissensu, published in Wittenberg in 1619, stated:

Nevertheless, most of those who today would be labelled iatrochemists follow Petrus Severinus, who has undertaken to bring the doctrines, expressed here and there by Paracelsus, back into the form of art, better than Paracelsus himself. For this reason I recognize a school today, as it were, which has been born and can be called Severinian. ${ }^{2}$

The seminal role of Severinus in spreading Paracelsian doctrines in the last quarter of the sixteenth century and making them internationally respectable has been emphasized by many of the leading scholars working in this field, such as Hugh Trevor-Roper, Allen

*Ole Peter Grell, MA, PhD, Carlsberg Research Fellow, Cambridge Wellcome Unit for the History of Medicine, University of Cambridge, Department of History and Philosophy of Science, Free School Lane, Cambridge CB2 3RH.

I J R Shackelford, 'Paracelsianism in Denmark and Norway in the 16th and 17th centuries', dissertation, University of Wisconsin, 1989, p. 129. See also A G Debus, The French Paracelsians: the chemical challenge to medical and scientific tradition in early modern France, Cambridge University Press, 1991, pp. 18-19.

2 D Sennert, De chymicorum cum Aristotelicis et Galenicis consensu ac dissensu Liber. Wittenberg, 1619 , p. 57. See also Shackelford, op. cit., note 1 above, p. 163, and A G Debus, 'Peter Severinus', in Dictionary of scientific biography, 14 vols, New York, Charles Scribner's Sons, 1970-80. 


\section{The Reception of Paracelsianism in early modern Lutheran Denmark}

Debus and Charles Webster. ${ }^{3}$ Comparatively little attention, however, has been given to the introduction and reception of Severinus's type of Paracelsianism in Denmark. ${ }^{4}$

In what follows I shall argue that a modified Paracelsianism, compatible with the "liberal", Melanchthonian theology which dominated the Danish, Lutheran State Church in the late sixteenth century, was introduced through Severinus and his friend, Pratensis. The fact that Lutheranism in Denmark remained largely unaffected by the doctorinal strife which engulfed Germany during the second half of the sixteenth century is of paramount importance for this development. Had this not been so, the attempt to introduce a modified Paracelsianism would have been doomed to failure.

The doctrinal conflict in Germany, which had been brought about by the dynamic growth of Calvinism and resurgent Counter-Reformation Catholicism, had among other things resulted in the controversy over crypto-Calvinism, where the so-called gnesioLutherans accused Melanchthon and his disciples of Calvinist tendencies, especially in their doctrine of the eucharist. What today seems an obscure debate between theologians had serious implications for contemporary politics and natural philosophy and resulted in a growing intolerance and doctrinal hardening in most of Europe. Denmark, not least thanks to its ruler, Frederik II, and the kingdom's leading theologian, the internationally renowned Niels Hemmingsen, both continued and developed a Philippist theology which was positively inclined towards Calvinism and new developments in natural philosophy and astrology.

Furthermore, I shall argue that this Severinian version of Paracelsianism remained an intrinsic part of natural philosophy and medicine in Denmark well into the seventeenth century in spite of the religious backlash generated by powerful exponents of Lutheran

\footnotetext{
${ }^{3}$ H Trevor-Roper, 'The Paracelsian movement', in idem, Renaissance essays, London, Fontana Press, 1986, pp. 149-99; Debus, op. cit., note 1 above; and C Webster, 'Essay review', Isis, 1979, 70: 591.

${ }^{4}$ Apart from the short introduction by E Bastholm to his edition of Severinus's Idea medicina, Petrus Severinus og hans Idea medicina philosophica, Odense Universitetsforlag, 1979, pp. $1-37$, and the recent thesis by Shackelford (op. cit., note 1 above), no integrated studies of Paracelsianism in Denmark and Norway have been undertaken. Sweden has been covered by $\mathrm{S}$ Lindroth,

Paracelsismen i Sverige till 1600-talets mitt, Uppsala, Almquist \& Wiksells Boktryckeri, 1943.

In addition to providing a translation by Hans Skov of Severinus's Idea medicina and making a number of sources, such as letters to and from Severinus, available in print for the first time, Bastholm's book provides little more than a biography of him and a brief introduction to his ideas. Shackelford's thesis, on the other hand, is a substantial piece of work which seeks to define Severinus's brand of Paracelsianism and to place it within the religious and political context of late sixteenth- and seventeenthcentury Denmark-Norway. However, I find two significant aspects of Shackleford's thesis
}

problematic. Firstly, his definition of Paracelsianism, where he sees Paracelsian cosmology and what Lindroth has termed religio Paracelsica as the constituent elements of Paracelsianism (pp. 230-1), is in serious danger of detaching Paracelsian natural philosophy from the changing religious context of the late sixteenth and early seventeenth centuries.

Furthermore, I find it difficult to see how Shackelford can include Severinus's type of Paracelsianism under this heading having defined it as eclectic. Secondly, I find Shackelford's account of the religious developments in Denmark in the early seventeenth century flawed (pp. 262-94). To see the Lutheran uniformity, which was promoted by Bishop Hans Poulsen Resen in particular, on a par with German Lutheran orthodoxy is a simplification which seriously distorts the religious picture and ignores the fact that the Book of Concord was outlawed in Denmark on its publication in 1580 and not directly referred to by Danish theologians until Jesper Brochmand's writings from the 1630s. Thus Resen, even where his views coincided with those of the orthodox Lutherans and the Formula of Concord, never referred to it, see B Kornerup, Biskop Hans Poulsen Resen, 2 vols, Copenhagen, G E C Gads Forlag, 1928-68, vol. 1, p. 348. 


\section{Ole Peter Grell}

uniformity, such as Hans Poulsen Resen and Jesper Brochmand who came to dominate the Lutheran church in Denmark in the second decade of the seventeenth century. ${ }^{5}$

\section{Severinus and Pratensis}

Both Peter Severinus and Johannes Pratensis had been carefully groomed for their appointments in 1571. Born into provincial, middle-class families in the early 1540 s they both matriculated at the University of Copenhagen in 1560 , where they appear to have befriended each other. The timing of the start of their university education could hardly have been more fortunate.

The Reformation and the re-foundation of the University of Copenhagen in 1537 had among other things brought the medical faculty within the realm of reality. Thus the first Protestant Vice-Chancellor of the University, Christian Torkelsen Morsing, was, in effect, the first professor of medicine ever to be appointed at the university. Lack of funds in the wake of the recent civil war (1534-36), however, made it impossible for the university to effect most of the improvements intended in the new Statutes during the reign of the Reformation King, Christian III (1536-59). Accordingly, it proved difficult to recruit candidates for a number of professorships, including the second professorship in medicine, and the University remained a backwater for a generation, badly in need of funds and unable to attract significant numbers of students.

At the time of Severinus's and Pratensis's matriculation, the university had, however, begun to feel the first effects of the improvements which were to be so thorough in the reign of Frederik II (1559-88). Denmark appears to have benefited more than most countries from the general economic boom in Europe during the second half of the sixteenth century, not least thanks to a growing demand for its agricultural products. Consequently, more money became available for the university. Salaries of professors improved dramatically, making these posts more attractive to talented and ambitious individuals. Further funds became available for education in general and the university in particular when the Seven Years' War with Sweden (1563-70) drew to a close. Thus in 1569 a Royal Trust was founded, providing stipends for 100 students. That year saw also the creation of four Royal stipends, which were to finance studies abroad for one medical and three theological students. ${ }^{6}$ Simultaneously, a number of aristocrats began sponsoring talented students at foreign universities, while employing a growing number of young graduates from the University of Copenhagen as tutors when sending their sons on the Grand Tour. Consequently the number of Danish students matriculating abroad saw an explosive growth in the decades after 1570. Numbers more than doubled between 1571 and 1600 , reaching 1,095, compared with the period immediately after the Reformation, 1536-1570, when only 528 students matriculated abroad. ${ }^{7}$

The talents of Severinus and Pratensis, who received their MAs in 1564 under the direction of the professor of natural philosophy, Nicolaus Scavenius, were quickly

\footnotetext{
${ }^{5}$ See T Lyby and O P Grell, 'The consolidation of Lutheranism in Denmark and Norway', in O P Grell (ed.), The Scandinavian Reformation,

Cambridge University Press, 1994, pp. 114-43.

${ }^{6} \mathrm{H}$ F Rørdam, Kjøbenhavns Universitets Historie fra 1537 til 1621, 4 vols, Copenhagen, Gyldendalske Boghandel, Nordisk Forlag, 1868-74, vol. 2, pp.
}

74-98. See also O P Grell, 'Caspar Bartholin and the education of the pious physician', in O P Grell and A Cunningham (eds) Medicine and the Reformation, London, Routledge, 1993, pp. 78-100.

${ }^{7}$ See V Helk, Dansk-Norske Studierejser fra Reformationen til Enevalden 1536-1660, Odense Universitetsforlag, 1987; for figures see p. 44, table 2. 
recognized by the government. Severinus was appointed Professor Pædagogicus, and Pratensis was made Headmaster of his old Latin school in Århus. ${ }^{8}$ At this stage Severinus, at least, was already aiming at a medical career. He had spent most of 1562 studying medicine in France and only a shortage of money had forced him to return home. Together with Pratensis, Severinus probably followed the lectures given by the recently appointed professor of medicine, Hans Frandsen (Johannes Franciscus). Frandsen, like his colleague in natural philosophy, Nicolaus Scavenius, had received part of his education abroad. Where Scavenius had studied in Wittenberg and Paris, Frandsen had studied in Tübingen under the famous Lutheran botanist/anatomist Leonhard Fuchs. A Galenist physician, Frandsen was deeply involved in the improvement of the teaching of medicine at the university. His friendship with the young Tycho Brahe, who had matriculated at the University in 1559, and the professor of theology, Niels Hemmingsen, may well have served to bring Severinus and Pratensis, while still students, into contact with these two leading figures of this period's Danish intelligensia. ${ }^{9}$

However, by the autumn of 1565 Severinus and Pratensis had gone abroad to pursue their medical studies in Germany, France and Italy. Since no royal stipends were yet available, King Frederik II, allowed the two students to share the salary from the still vacant second professorship in medicine. This was done, as the King explicitly stated, so that either or both of them could be employed as professors of medicine at the University in Copenhagen when they had finished their studies. ${ }^{10}$

Severinus and Pratensis probably received their doctorates in France either in the autumn of 1569 or some time before November $1570 .{ }^{11}$ They had by then visited most of the leading universities in Europe, spending part of 1569 in Basle where they had befriended Theodor Zwinger, who like them was interested in Paracelsianism, and who became a regular correspondent of Severinus. ${ }^{12}$ Furthermore, by November 1570 Severinus had finished his Idea medicina which was published in Basle the following year. Meanwhile, another short work by Severinus, Epistola scripta Theophrasto Paracelso, basically an advertisement for the Idea medicina, had already been published by the same Basle printer at the end of 1570 or beginning of $1571 .^{13}$

\section{Idea medicina}

Severinus opportunely dedicated Idea medicinae to his royal benefactor. Praising the King's generosity he stated that: "Kings, also absolute monarchs, have previously taken

\footnotetext{
${ }^{8}$ Rørdam, op. cit., note 6 above, vol. 2, pp. $486-90,574$ and 600.

${ }^{9}$ Niels Hemmingsen dedicated his famous work Syntagma institutionum Christianarum, Basle, 1574, to Hans Frandsen. It was this work which eventually led to his suspension from his university post in 1579 , accused of crypto-Calvinism, see Rørdam, op. cit., note 6 above, vol. 2, p. 553. For Pratensis's early friendship with Tycho Brahe, see entry for Brahe in Dansk Biografisk Leksikon, 3rd ed. Copenhagen, Gyldendalske Boghandel, Nordisk Forlag, 1979-84, henceforth $D B L$.

${ }^{10}$ Rørdam, op. cit., note 6 above, vol. 2, pp. 574-5, and Grell, 'Caspar Bartholin', op. cit., note 6
}

above, p. 86; Frederik II's letter is printed in J D Herholdt and F V Mansa (eds), Samlinger til den danske Medicinal-Historie, vol. 1, Copenhagen, Gyldendal, 1833-35, pp. 16-17.

${ }^{11}$ See Rørdam, op. cit., note 6 above, vol. 2 , p. 576, note 2. It has been argued that Pratensis received his docorate in Padua, see $\mathrm{V}$ Ingerslev in Danmarks Lager og Lagevasen, 2 parts,

Copenhagen, E Jespersen, 1873, p. 157.

12 See the letters written by Severinus to Zwinger printed in Bastholm, op. cit., note 4 above, pp. 45-57.

${ }^{13}$ For the dating of this work, see Shackelford, op. cit., note 1 above, pp. 37-9. 


\section{Ole Peter Grell}

such intellectual products under their gracious protection. They themselves have also to the great benefit of people ardently explored the secrets of nature". This was an allusion to Frederik II's and Queen Sophie's interest in iatrochemistry. ${ }^{14}$ Evidently, Severinus must have expected a positive response to his dedication, which also comprised what amounted to a manifesto for medicine. Thus he pointed out that he had come to realize that Galen's theories and remedies were inadequate, but while in Germany he had heard Paracelsus's remedies praised. This statement would seem to contradict the emphasis of modern scholars on the French inspiration for Severinus's Paracelsianism. Considering his known correspondence and friendship with Theodor Zwinger in Basle, it is somewhat surprising that this specific reference by Severinus to Germany has been ignored. Even more so when it is borne in mind that "the Basle-connection", established by Severinus, became the most significant foreign influence on the medical faculty in Copenhagen until 1639. ${ }^{15}$

Severinus claimed that this praise had led him to study Paracelsus's writings, which he had found difficult to understand, and which had only gradually become comprehensible to him via his studies of Hippocrates and Plato. It had led Severinus to the following conclusion:

First and foremost, they [physicians] should bring about the revival of the idea of human freedom and consider how best to restrain immediate misfortunes. Second, they should study nature, its causes and peculiarities and not be deterred from such an important task by difficulties, costs and exertions. We do not owe the Greeks nor Arabs any respectful consideration. We are the servants of the sick, for whom God has created medicine, and after its creation entrusted to our care. ${ }^{16}$

Severinus was, in other words, an early and forceful advocate of an open-minded, empirical type of medicine. For him natural philosophy was not merely passive contemplation, but first-hand experience. These aspects of his philosophy were undoubtedly his most enduring legacy to Danish medicine and came to characterize the approach of other dominant figures of the period, such as Caspar Bartholin, Ole Worm and Thomas Bartholin.

In placing his version of Paracelsianism firmly within the Hippocratic tradition Severinus was in agreement with friends and admirers such as Thomas Moffett and Theodor Zwinger. ${ }^{17}$ The eclectic Paracelsianism advocated by Peter Severinus was highly critical of scholastic medicine and Galenic pathology. It fitted into the Paracelsian rhetoric of reform, but it had, significantly, been cleansed of all popular and radical elements. It was a compromise between traditional university medicine and Paracelsianism, as can be seen from the conclusion of the Idea medicina. Here Severinus stated:

In these meditations I have explained for which diseases and for what reasons the instructions and diagnoses of Galen are appropriate. Those, who believe that we want to abolish all cures which

\footnotetext{
${ }^{14}$ Peter Severinus, Idea medicina philosophicae, fundamenta continens totius doctrina Paracelsica. Hippocratica, \& Galenica, Basle, 1571, fol. B2r. An annotated MS-copy of Paracelsus's Wundartzney and Theoria chirurgia with a dedication to Frederik II is preserved in the Royal Library in Copenhagen, Ms., Gl. kgl. Saml. No. 1669, 4.
} 


\section{The Reception of Paracelsianism in early modern Lutheran Denmark}

have been recognized for generations, are mistaken. It is a safer method gradually to correct mistakes, energetically causing the physicians, actively and quietly, to explore nature and the conditions which cause cures and from where the vital processes emanate. ${ }^{18}$

This moderate programme, however, needed to be effectuated urgently. Severinus expressed the hope that

the Almighty would re-direct those who had lost their way and split the darkness, in order that mankind, after having found the sacred harmony which God had promised in his only begotten Son, could enjoy eternal understanding, as participants and citizens of the heavenly Jerusalem.

This sense of eschatological imminence, reminiscent of Paracelsus, but much milder in tone, was echoed by Severinus's friend Pratensis in the poem he wrote for the Idea medicince. ${ }^{19}$ What they both had in mind was evidently a Melanchthonian reformation of medicine on a par with the recent religious Reformation.

\section{Pratensis and Paracelsianism}

Upon their return to Denmark in June 1571 Severinus was immediately appointed royal physician to Frederik II, while Pratensis had to wait only a fortnight before being given the still vacant second chair in medicine. Hardly a surprise, considering that Severinus and Pratensis had been especially groomed for it. From the discussion surrounding Pratensis's appointment it appears that some reservations existed within the university about his Paracelsianism. Pratensis's candidature, however, was promoted by the then Vice-Chancellor, the theologian, Niels Hemmingsen, at the instigation of the influential court preacher Niels Nielsen Kolding, who was the inspiration behind many of Frederik II's educational initiatives. ${ }^{20}$ The demand that Pratensis should teach only Hippocratic and Galenic medicine in accordance with what was taught at the universities in Wittenberg and Leipzig reflected some unease about Paracelsianism in general, but was a prudent political move which made Pratensis's appointment generally acceptable. Had Hemmingsen been in agreement with Peder Palladius (1537-60), his predecessor as the kingdom's leading theologian who had been strongly opposed to Paracelsianism and alchemy, he would surely have done his utmost to avoid Pratensis altogether. ${ }^{21}$ As early as 27 August 1571, Pratensis joined Hans Frandsen in lecturing at the medical faculty. ${ }^{22}$ He appears to have disregarded the restrictions imposed on his teachings from the outset, as can be seen from a letter he wrote to Peter Severinus a couple of years later:

\footnotetext{
${ }^{18}$ Severinus, op. cit., note 14 above, pp. 406-7.

${ }^{19}$ Ibid., p. 408 and fols. GG-HH1r.

${ }^{20}$ According to the headmaster of the Latin school in Ribe and later Bishop, Peder Hegelund, Severinus and Pratensis returned to Denmark on 22 June 1571, see B Kaae (ed.), Peder Hagelunds Almanakoptegnelser 1565-1613, vol. 1, Ribe, Historisk Samfund for Ribe Stift, 1976, p. 71. Pratensis's appointment was discussed by the governing body of the university on 3 July 1571 , see Herholdt and Mansa, op. cit., note 10 above, pp. 148-9. For Niels Nielsen Kolding, see $D B L$, Kolding
}

\author{
was close to Hemmingsen as can be seen from one of \\ his edifying books, De besynderligste Historier. . ., \\ Copenhagen 1567, to which Hemmingsen wrote the \\ introduction. \\ ${ }^{21}$ Grell, 'Caspar Bartholin', op. cit., note 6 above, \\ p. 87. For a somewhat different interpretation of these \\ events, see J R Shackelford, 'Paracelsianism and \\ patronage in early modern Denmark', in B T Moran \\ (ed.), Patronage and institutions: science, \\ technology, and medicine at the European court, \\ 1500-1750, Suffolk, Boydell Press, 1991, pp. 92-4. \\ ${ }^{22}$ Kaae, op. cit., note 20 above, p. 73.
}




\section{Ole Peter Grell}

From the beginning I was quietly happy, when through the secret and clever art of Proteus I could fetch such beautiful and splendid flowers from foreign gardens, which I planted in place of Galen's weeds to the great astonishment of worthy men, because for a long time it had escaped our teachers that considerable obscurity was hidden in Galen. But now, when they too have had the chance to explore foreign gardens, I cannot keep quiet any longer after the delusion has been unmasked by some inventive new philosophers.

Pratensis had evidently taken the less controversial step of introducing his type of Paracelsianism through the back door, in the form of criticism of Galen. This low-key approach had, according to the letter, borne fruit and converted some of his more conservative colleagues. That this was not just boasting is confirmed by the pamphlet the university issued at his death in 1576, praising him for his exposition of both medical systems, "the Galenic and the Paracelsian", in which "his ingenuity, fortune and enterprise was famous and divine". ${ }^{23}$ Thus, Pratensis, like his friend Severinus, promoted an eclectic Paracelsianism, in an irenic and non-confrontational form, which was compatible with elements of Galenic medicine, and caused minimum hostility among conservative scholars at the university.

\section{Pratensis and Tycho Brahe}

Only six months before Pratensis and Severinus had returned to Denmark, the noble scholar, Tycho Brahe, who was to acquire European fame in astronomy, had returned from his studies abroad. It was undoubtedly through the leading professor in the medical faculty, Hans Frandsen, whom he had known from his student days, that Tycho Brahe had come to know Severinus and Pratensis; and following their return to Copenhagen in the summer of 1571 the acquaintance was renewed. Pratensis in particular became close to Tycho Brahe, who often stayed with him when visiting Copenhagen. Together with Brahe's cousin, Peder Oxe, who had recently returned from exile to take up the influential position as Lord High Steward within the government of Frederik II, Pratensis was instrumental in convincing Brahe to publish his discovery of the new star in 1572 . Thus, it was a letter from Pratensis to Brahe which prefaced De stella nova in 1573, while a poem by their mutual friend, Hans Frandsen, graced the front of the book. ${ }^{24}$ Pratensis also played a considerable part in convincing Tycho Brahe to lecture on astronomy at the University of Copenhagen in 1574-75. These lectures expressed a similar flexible Paracelsianism, leaving room for Galenism, like that professed by Pratensis and Severinus. The lectures were well received by the academic establishment in Copenhagen, including the kingdom's leading theologian, Niels Hemmingsen. ${ }^{25}$

\footnotetext{
${ }^{23}$ For Pratensis's letter to Severinus, see Bastholm, op. cit., note 4 above, p. 40 . The statement from the pamphlet issued by the university is quoted by Bastholm, pp. 6-7.

${ }^{24}$ For Peder Oxe, who had spent the years 1532-37 at foreign universities under the tutelage of the later professor of medicine, Christen Torkelsen Morsing, see $D B L$; for Pratensis's friendship with Brahe, see Rørdam, op. cit., note 6 above, vol. 2, pp. 601-2, and V E Thoren, The Lord of Uraniborg: $a$
}

\author{
biography of Tycho Brahe, Cambridge University \\ Press, 1990, pp. 43, 62-5, 69-72, 113. For \\ Lutheranism and astrology, see S Kusukawa, \\ 'Aspectio divinorum operum: Melanchthon and \\ astrology for Lutheran medics', in Grell and \\ Cunningham, op. cit., note 6 above, pp. 33-56. \\ $25 \mathrm{~J}$ L E Dreyer, Tycho Brahe: a picture of \\ scientific life and work in the sixteenth century, \\ Edinburgh, Adam and Charles Black, 1890, pp. 73 \\ and 131, and Thoren, ibid., pp. 79-85. Like
}




\section{The Reception of Paracelsianism in early modern Lutheran Denmark}

Furthermore, the early 1570s were the years when Tycho Brahe was preoccupied with alchemical work rather than astronomy. This preference was undoubtedly connected to his friendship with Pratensis. The sudden death of Pratensis in 1576, while lecturing to his students, made a deep impression on Brahe. He wrote to Peter Severinus and asked him to compose an epitaph for the gravestone he was having cut. Brahe himself composed a Latin epitaph of sixty lines, describing his friend as "a brilliant man who possessed all sorts of virtues and education and was an excellent doctor of both Paracelsian and Galenic medicine". ${ }^{26}$

\section{Severinus and Paracelsianism}

Meanwhile Peter Severinus remained as royal physician-a position he continued to occupy until his death in 1602. In spite of being busily occupied at court, he found time to write on both natural philosophy and medicine. However, he never published another work in spite of the fame and success of his Idea medicinae. There was no shortage of encouragement to publish from his friends. Both Theodor Zwinger in Basle and Thomas Moffett in England wanted him to join the European debate about Paracelsianism. But, as Severinus wrote to Zwinger in February 1583, he had been deeply disappointed by "how severely and with what disloyal arguments certain opponents had received his works". Accordingly, Severinus had opted for "silence, being a stranger to controversy and abuse". ${ }^{27}$ Severinus's irenicism and dislike of argument was not new, it had already been in evidence in the Idea medicina, and was a position he shared with some of the leading theologians in Denmark, in particular Niels Hemmingsen. Thus when Severinus wrote to his friend, the minister Johannes Pistorius, in the mid-1570s, he expressed his sympathy for the embattled Hemmingsen, whose recent book Syntagma institutionum christianarum had caused him to be accused of crypto-Calvinism: "Nature loves silence and God curses the quarrelsome. Enough of that, in fact, more than enough. I feel sorry for the theologians in these times. To live in peace and quiet is the safest". ${ }^{28}$

The fact that Hemmingsen's book, after pressure from abroad, caused him to be suspended from his professorship in theology in 1579 may well have encouraged the irenically inclined and naturally cautious Severinus to avoid publishing any further works himself. The growing doctrinal confrontation between "liberal" Philippists and hardline gnesio-Lutherans in Gemany had shown that it could easily affect developments in Denmark. Hemmingsen's case had served to demonstrate that even fairly minor points of

Melanchthon, Hemmingsen considered astrology an important science. In a letter to Henrik Rantzau from 1593 he admitted that he knew little of astrology, but he believed 'all events had their causes, necessary or accidental, and that the exceptionally skilled could read future occurrences from the Book of Nature which God has written like unto a tablet', J GlebeMøller, 'Socialetiske aspekter af Niels Hemmingsens forfatterskab', in Kirkehistoriske Samlinger, 1979 , pp. 7-56, p. 24 (my translation).

${ }^{26}$ For Tycho Brahe's interest in alchemy and Paracelsianism, see Shackelford, op. cit., note 1 above, pp. 203-10 and idem, op. cit., note 21 above, pp. 95-105. For Tycho Brahe's epitaph, see J L E Dreyer (ed.), Tychonis Brahe dani opera omnia, 15 vols, Copenhagen, Nielsen and Lydiche, 1913-29, vol. 9, pp. 176-7.

${ }^{27}$ For Severinus's letter to Zwinger, dated 23 February 1583, see Bastholm, op. cit., note 4 above, pp. 45-9, especiallyp. 46; for Thomas Moffett's encouragement, see his De jure et prastantia chymicorum medicamentorum, Frankfurt, 1584, p. 7; see also Shackelford, op. cit., note 1 above, pp. 135-6.

${ }^{28}$ For Severinus's letter to Pistorius, see Bastholm, op. cit., note 4 above, pp. $39-40$, especially p. 40. 


\section{Ole Peter Grell}

heterodoxy could have serious consequences. ${ }^{29}$ Silence was the only safe option, even for someone like Severinus who advocated a very "moderate" form of Paracelsianism. That Severinus avoided all suspicion of heterodoxy can be seen from his involvement in the revision of the Danish Bible which began towards the end of Frederik II's reign. If any doubt had existed about his orthodoxy he would hardly have been asked to revise the first four chapters, including the, from a Paracelsian perspective, all-important first chapter of Genesis. ${ }^{30}$ Furthermore, when Severinus wanted the vacant professorship in medicine in 1602 no objections against his Paracelsian leanings appear to have been raised, and only his sudden death during an epidemic prevented him from taking up his chair.

\section{Paracelsianism in Seventeeth-Century Denmark}

By the beginning of the seventeenth century most, if not all, of the first generation of eclectic, Danish Paracelsians had died, including Tycho Brahe and the professor of natural philosophy, Anders Kragh, who had served the university in various professorial capacities since 1586. Kragh had been a fervent defender of Peter Ramus and an active iatrochemist, and he had advised his students in Copenhagen to avoid being bound by Galen and Aristotle. Like his colleagues at the university, Kragh had been an exponent of a flexible Paracelsianism which paid due respect to Galen. ${ }^{31}$

By then only Tycho Brahe's former assistant, Cort Aslaksen, who eventually became professor of theology in 1607, actively promoted the Severinian version of Paracelsianism within the university. ${ }^{32}$ At the Court, however, Christian IV continued the tradition begun by his father of employing a physician/iatrochemist who was positively inclined towards Paracelsianism. In 1609 the King built a distillation house in the garden of Rosenborg Castle and employed the Paracelsian physician, Peter Payngk, who had recently returned from the court of Emperor Rudolph II in Prague. Payngk remained in Christian IV's employment as royal chemist. He appears to have been busily engaged in providing chemical preparations and medicine for the King, the court, and the nobility until his retirement, shortly before his death in 1645. Like his predecessor, Peter Severinus, he too appears to have been an eclectic Paracelsian. ${ }^{33}$

An important change, however, had by then taken place within the political domain in Denmark. Christian IV had come of age in 1596 and the regency which had followed the death of Frederik II in 1588 ended. By then the men who had dominated the government since the end of the Seven Years' War with Sweden, Peder Oxe and Chancellor Niels Kaas, who had both actively supported Niels Hemmingsen, Tycho Brahe and Peter Severinus, were all dead. Under the leadership of the new Chancellor, Christian Friis of Borreby (1596-1616), the power of the state was considerably enhanced. These developments eventually led to the introduction of a fully fledged absolutism in 1660 .

\footnotetext{
${ }^{29}$ For Niels Hemmingsen, see the article by GlebeMøller, op. cit., note 25 above, pp. 7-56.

${ }^{30}$ Rørdam, op. cit., note 6 above, vol. 2, p. 247.

${ }^{31}$ Ibid., vol. 3, pp. 508-21; for Kragh's

Paracelsianism, see his letter to Dr Sigismund

Schnitzer in T Bartholin, Cista medica Hafniensis, Copenhagen, 1662, pp. 109-12.

${ }^{32}$ Rørdam, op. cit., note 6 above, vol. 3, pp.
}

585-99; see also C Aslaksen, De natura cali triplicis, Siegen, 1597, which was dedicated to Tycho Brahe and his Physica et ethica Mosaica, Hanover, 1613, which was dedicated to the Chancellor, Christian Friis of Borreby. See also O Garstein, Cort Aslakssøn, Oslo, Lutherstiftelsen, 1953.

${ }^{33}$ See Shackelford, op. cit., note 21 above, pp. 106-8. 


\section{The Reception of Paracelsianism in early modern Lutheran Denmark}

The desire to create a stronger and more centralized state also affected the Lutheran Church in Denmark, where the recently appointed professor of theology, Hans Poulsen Resen (1597) in close collaboration with Christian Friis of Borreby took steps to create a more uniform Church. Such action was made particularly urgent by the growing impact of Counter-Reformation Catholicism and Calvinism in Scandinavia. Resen's campaign for uniformity within the Lutheran Church led to a number of prominent "liberal" Philippists or crypto-Calvinists of the Hemmingsen ilk losing their jobs in the university and the Church in the second decade of the seventeenth century. Resen and Friis, however, cannot be described as orthodox gnesio-Lutherans-the Book of Concord which had been anathema in Denmark since the reign of Frederik II continued to be rejected-instead, they wanted a uniform Church for political and ecclesiastical reasons.

In ecclesiastical terms, Resen was a Danish equivalent to Archbishop William Laud in England. Accordingly, he cannot be seen to have nurtured any animosity towards the "moderate" Paracelsianism and Ramism which continued to exist within the university. If anything, Resen's inclination towards mysticism and a neo-Platonic natural philosophy would have made him positively inclined towards such views, while his participation in the reform of the Latin schools in 1604 demonstrates his Ramist leanings. Thus it was not the Paracelsian bias of his co-professor of theology, Cort Aslaksen, which worried him in the years 1611-14, but Aslaksen's perceived crypto-Calvinism. ${ }^{34}$ Furthermore, Resen did not remain unaffected by the pre-Pietist Lutheranism of his noble friend, Holger Rosenkrantz, whose theology was inspired by the German theologian, Johann Arndt. Rosenkrantz, like Arndt, wanted to complete with a reformation of life the reformation which Luther had begun in teaching. The government's 1623 prohibition of swearing, together with its ruling that holy days should be observed and the penitential ordinance of 1629 , which were all geared towards improving piety among the people, demonstrate the pre-Pietist influence on Resen's ecclesiology. 35

Furthermore, the neo-Platonic and speculative aspects of Resen's theology are strongly in evidence in his writings that precede his confrontation with the crypto-Calvinists in the Danish church in 1614. There are, for example, considerable overlaps between important aspects of Resen's theology and that of the spiritualist Sebastian Franck whose ideas were close to those of Paracelsus. ${ }^{36}$ Resen, who owned and heavily annotated a copy of Franck's Paradoxa, advocated similar ideas about Christ's eternal omni-presence in Nature. Likewise, Resen's teaching about “unio mystica", concerning Christ's innate presence in the re-born Christian, is likely to have been inspired by his reading of Johann Arndt's Vier Bücher von wahren Christenthum. Thus further aspects of Resen's theology appear to have been influenced by another German Protestant theologian who was positively inclined towards Paracelsianism. ${ }^{37}$

\footnotetext{
${ }^{34}$ For Peder Oxe, Niels Kaas and Christian Friis of Borreby, see DBL. For Hans Poulsen Resen, who befriended Giordano Bruno while a student in Wittenberg, see $D B L$; see also Kornerup, op. cit., note 4 above. For the Counter-Reformation, see V Helk, Laurentius Nicolai Norvegus S.J., Copenhagen, G E C Gads Forlag, 1966.

${ }^{35}$ H F Rørdam (ed.), Danske Kirkelove, 3 vols, Copenhagen, Selskabet for Danmarks Kirkehistorie, Thieles Bogtrykkeri, 1883-89, vol. 3, pp. 98-102 and 140-69. For Resen's friendship with Rosenkrantz,
}

see J O Andersen, Holger Rosenkrantz den larde, Copenhagen, August Bangs Boghandels Forlag, 1896, pp. 133-8.

${ }^{36}$ For Sebastian Franck and Paracelsus, see W Pagel, Paracelsus: an introduction to philosophical medicine in the era of the Renaissance, 2 nd ed., Basle, Karger, 1982, pp. 40-2.

${ }^{37}$ For the influence of Sebastian Franck on Resen's theology, see Kornerup, op. cit., note 4 above, vol. 1, pp. 354, 391, 430 and 458. Resen owned a heavily annotated copy of Arndt's Vier 


\section{Ole Peter Grell}

Resen did not come out of the theological confrontation with the cryto-Calvinists in 1614 totally unscathed. He was forced to promise to refrain from publishing theological tracts similar to his recent neo-Platonic, Christological disputations, but does not appear to have changed his views. In fact, Resen's subsequent writings demonstrate that he did not fully adhere to his promise. At most, it resulted in the mystic elements in his theology becoming less conspicuous. Thus Resen never disowned neo-Platonism, even if he made a point of dismissing Rosicrucianism as dangerous religious fanaticism. ${ }^{38}$

\section{The Influence of Rosenkrantz}

Holger Rosenkrantz became the leading exponent of a pre-Pietist variety of Lutheranism in early seventeenth-century Denmark, which advocated a return to a purely Scripture-based theology with an emphasis on double justification through faith and acts. He influenced not only a number of prominent theologians and bishops within the Danish Church, but also a whole generation of Danish scholars in a variety of fields. The school he established on Rosenholm, his estate in Jutland, provided teaching in a number of subjects, such as Greek, Hebrew, mathematics and astronomy, and Rosenkrantz's advocacy of reform was not restricted to theology. He had befriended Tycho Brahe in 1592 and occasionally assisted Brahe in his research. John Dury, the great advocate of Protestant unity in the early seventeenth century, considered Rosenkrantz to be the most learned and pious man in all Germany, while Dury's correspondent, Sampson Johnson, pointed out that "all great schollars of Denmark had their first grounds of learning from his house". 39

Like his German inspirer, Johann Arndt, who had studied medicine under Theodor Zwinger in Basle, Rosenkrantz was undoubtedly a supporter of some form of moderate Paracelsianism. ${ }^{40}$ Thus, Rosenkrantz's wife, Sophie Brahe, Tycho Brahe's niece, regularly bought chemical preparations from Peter Payngk in Copenhagen, while he himself was associated with two radical, Paracelsian-inspired medical practitioners, Hartvig Lohmann and Nicolaus Teting who frequently found themselves in trouble with the authorities because of their heterodox religious views. ${ }^{41}$ Like Rosenkrantz, Teting and Lohmann were inspired by Arndt and other German, pre-Pietist Lutherans such as Valentin Weigel. Unlike the educated physician, Nicolaus Teting, Lohmann eventually found himself in trouble not only because of his religious views, but also because of his medicine. Lohmann's troubles are worth rehearsing because they illustrate the official attitude to moderate Paracelsianism in early seventeenth-century Denmark.

\section{Paracelsianism versus Witchcraft}

Lohmann, a self-taught, immigrant empiric from Schleswig, had settled in the town of Odense around 1630, having left his position as town clerk of Flensburg in 1622, after

Bücher von wahren Christenthum, Jena 1607, see ibid., vol. 1, p. 372.

${ }^{38}$ Ibid., vol. 2, pp. 32 and 124.

39 Andersen, op. cit., note 35 above, pp. 90 and 112-14. See also G H Turnbull, Hartlib, Dury and Comenius, London, Hodder \& Stoughton, 1947, p. 159. For the quotation, see P G Westin, Negotiations about church unity, 1628-1634, Uppsala Universitets årsskrift, 1932, p. 279.
${ }^{40}$ Lindroth, op. cit., note 4 above, pp. 432-7.

${ }^{41}$ For Teting's association with Rosenkrantz, see Sheffield University Library, Hartlib Papers MSS, 'Ephemerides' 1635, 29/3/15A: "Teting is very intimate with Lord Rosencrantz who is framing by Education et Learning a New Commonwealth being the father of every one in particular". For Nicolaus Teting, see also $D B L$. 


\section{The Reception of Paracelsianism in early modern Lutheran Denmark}

being accused of religious heterodoxy. Odense, the main administrative and urban centre of the Danish island of Funen, was then without a resident physician. Upon his arrival, Lohmann appears to have developed an extensive and successful practice, using primarily Paracelsian remedies. Apart from some doubts about his religious orthodoxy, which were raised in 1632 and which led the local minister to visit him, his work and residence in Odense, where he had bought a house, seem to have caused no problems. His troubles, however, began in the summer of 1634, a year after the local gentry had recruited a physician, Dr Henrik Køster. Køster was disappointed with the business he was able to attract in Odense where even some of his prospective customers among the gentry continued to prefer the services of Lohmann. ${ }^{42}$

Considering the speed with which Henrik Køster became involved in the case against Lohmann that, at least initially, was supposedly about his perceived religious heterodoxy only, it is reasonable to assume, as did Lohmann himself, that Køster was one of the leading instigators in the case, working hand in glove with the local Bishop and Lord Lieutenant. ${ }^{43}$ Lohmann, however, had strong support among the burghers of Odense who openly criticized the Bishop for taking action against the popular empiric. ${ }^{44}$ This proved to be of little avail since Lohmann was summoned before the local Consistory Court in November.

In his two written responses to the Court Lohmann emphasized his orthodoxy in vague and general terms, pointing to the Bible and the works of Luther and Johann Arndt as his authorities. It is, however, evident from these replies that by now he also stood accused of practising some sort of black magic. It was therefore necessary for Lohmann, who used the title of "Chymicus and Medicus", to underline that his cures of more than a hundred people, including several of the local gentry, had not been due to the use of "unchristian and unnatural" means, but were the result of the assistance of God and the use of natural remedies. Likewise, Lohmann emphasized that he studied only the publicly approved imprints of Paracelsus and others, and then not for theological reasons, but for the true natural philosophy, chemistry and medicine to be found in them. ${ }^{45}$ Realizing that the local Consistory Court assisted by the Lord Lieutenant was on the verge of expelling Lohmann from town and realm, a group of leading burghers in Odense, including several town-councillors, petitioned King Christian IV on his behalf around Christmas $1634 .^{46}$

On 2 January 1635 Lohmann added his own petition to that of the burghers, requesting that his case be removed from the local court to one appointed by the King and presided over by Holger Rosenkrantz. Although Lohmann did not succeed in getting the sympathetic Rosenkrantz to sit in judgement on him, during that month the King ordered the case to be referred to the Consistory Court in Copenhagen. Here Lohmann was accused of being a dangerous religious heterodox and empiric, whose fortunate cures had been brought about by knowledge gathered from suspicious books. Two in particular,

\footnotetext{
42 See the correspondence between Ole Worm and Henrik Køster, H D Schepelern (ed.), Breve fra og til Ole Worm, 3 vols, Copenhagen, Munksgaard, $1965-68$, nos. 472,514 and 564.

${ }^{43}$ Most of the documents relating to the case against Lohmann have been published by $\mathrm{H} \mathrm{F}$

Rørdam, 'Hartvig Lohman i Odense, et kirkehistorisk
}

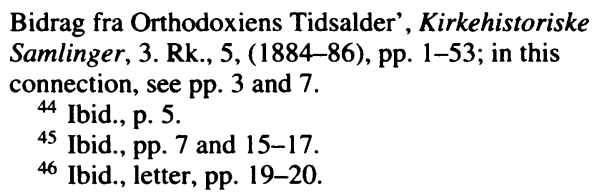




\section{Ole Peter Grell}

were mentioned. According to the bookbinder who had bound these works, they contained illustrations of "God, the Father, Son and Holy Ghost and the hands of Moses holding two tablets". The text of the tablets had been replaced with "peculiar mirrors" with inscriptions which could be read only at night. ${ }^{47}$ Eventually Lohmann saved his skin by proving his orthodoxy through subscribing to the Augsburg Confession and the Stranger Articles of 1569. Thus, it was not Lohmann's Paracelsian cures which worried the authorities, but his perceived heretical religious views that resulted from his extensive reading of Arndt. Likewise, it had not been by accusing him of practising Paracelsian medicine, but rather by trying to have him charged with practising black magic, that Køster and his co-instigators in Odense had sought to get him convicted and removed. Accordingly, as soon as he had conformed, Lohmann was granted leave by the King to continue to reside in Odense and to offer his medical services to the population. ${ }^{48}$

Lohmann, however, was not the first Paracelsian practitioner in Odense who found himself accused of black magic in the early seventeenth century. Seventeen years earlier, at a time when Christian IV and his government were becoming increasingly worried about superstition and witchcraft, which eventually resulted in the legislation against witchcraft of 12 October $1617,,^{49}$ an elderly barber-surgeon, Hans Schult, found himself accused of practising black magic. In an attempt to cure his own impotence Schult had had a three-pronged fork made, on which certain symbols were engraved. It had been produced by a local blacksmith at "the hour of Saturn" and had been engraved before sunrise the following Sunday and then placed in a local brook. Here it had accidentally been discovered and Schult was consequently accused of witchcraft and of having entered into a pact with the Devil. He defended himself, however, by pointing out that his actions had nothing to do with black magic, emphasizing that he had acquired his knowledge from the works of the "learned Theophrastus Paracelsus", and that the method was known and used among barber-surgeons. Furthermore, he pointed out to the court, it was "generally accepted among many of the most learned men that metal, be it gold, silver, iron, etc., like running water, contained the power to heal". This was probably an oblique reference to Christian IV's well-known Paracelsian chemist, Peter Payngk. Schult's defence proved sufficient and the case against him was droppedParacelsian healing was clearly acceptable as long as it could disassociate itself from suspicions of superstition and witchcraft. ${ }^{50}$

\section{Rosenkrantz's Influence on Bartholin and Worm}

Holger Rosenkrantz's influence on, and contacts with, Paracelsian practitioners like Teting and Lohmann, was significant, but it was less important than the influence he exercised over the two most influential professors of medicine at the University of

\footnotetext{
47 Ibid., pp. 33-5.

48 Ibid., pp. 28-53, and Andersen, op. cit., note 35 above, pp. 314-15. See also B Kornerup and H Kock (eds.), Den danske Kirkes Historie, Copenhagen, Gyldendal, 1959, vol. 4, pp. 330-2. For Lohmann, see also $D B L$.

${ }^{49}$ For witchcraft in this period, see J Chr Johansen, 'Faith, superstition and witchcraft in Reformation
}

\author{
Scandinavia', in O P Grell (ed.), The Scandinavian \\ Reformation: from evangelical movement to \\ institutionalisation of reform, Cambridge University \\ Press, 1994, pp. 179-211. \\ ${ }^{50}$ For this case, see E Ladewig Petersen, \\ $\mathrm{K} \mathrm{J}$ V Jespersen, and L Jespersen, De fede År. \\ Odense 1559-1660, Odense Universitetsforlag, 1984, \\ pp. 325-9.
}




\section{The Reception of Paracelsianism in early modern Lutheran Denmark}

Copenhagen, Caspar Bartholin and Ole Worm. While still abroad, Bartholin had recognized Rosenkrantz's importance in Denmark and consequently, in December 1610, he dedicated his textbook, Institutiones anatomicae (1611), to him. He praised not only Rosenkrantz's piety and learning in general, but emphasized that he was also the owner of a considerable medical library, and a herbarium, to say nothing of his substantial knowledge of pharmacy. He was in other words a highly appropriate noble patron for an ambitious, young physician. ${ }^{51}$

From his appointment as professor of medicine in Copenhagen in 1613 until his death in 1629, Caspar Bartholin was keenly interested in Paracelsian medicine. His early interest is evident in the first medical disputations he presided over in 1613 and 1614: De philosophiae in medicina usu et necessitate and Exercitatio disputationis secundoe ordinaria. ${ }^{52}$ Throughout his life, even after he had left the medical faculty to become professor of theology, Bartholin continued to promote an eclectic Paracelsianism close, if not identical, to that introduced in Copenhagen forty years earlier by Severinus and Pratensis. Thus, in 1626 he wrote a manual for the study of medicine dedicated to a relation, Peder Charisius, who was also the grandson of Peter Severinus. In the introduction to De studio medico (published in 1628) Bartholin referred to Severinus as "of blessed memory, the unrivalled physician and spagyrist of his age, whose fame was celebrated everywhere". In the manual he warmly recommended iatrochemistry as essential to the aspiring physician. It was a subject which should be studied day and night, and the student should not only rely on the works and chemical arcanae of such leading lights as Joseph Duchesne and Oswald Croll, but should seek information everywhere possible. He considered the arcana of Peter Severinus, Tycho Brahe, John Bannister, Johannes Hartmann and even King Christian IV particularly useful, while referring students to his own extensive alchemical library.

Bartholin acknowledged the negative attitude among traditional, Galenic physicians to alchemical medicine, but stressed that "while the one should be pursued, the other should not be neglected". In this connection, Bartholin emphasized the need for personal and practical experience in the field, underlining the importance of experimenting with alchemy and "its charcoal and glass flasks". He added that no one should be ashamed to seek information from old wives and barbers about their remedies, nor to use them as long as they had proven effect. ${ }^{53}$ These were opinions which resembled those held by Severinus and Pratensis and they demonstrate that a moderate Paracelsianism remained important within the medical faculty of the University of Copenhagen.

Similarly, Caspar Bartholin was in agreement with Severinus and Pratensis about the eschatological urgency of medical, as well as, religious reform. This is in evidence in all the textbooks and manuals he produced in the 1620s and in the draft for new Statutes of the university he co-authored in 1621, which included plans for a major reform of medicine. ${ }^{54}$

51 Grell, 'Caspar Bartholin', op. cit., note 6 above, pp. 78-100.

52 See C Bartholin, De philosophiae in medicina usu et necessitate 17 Nov. 1613, fols. A2r-A3r, Br; and idem, Exercitatio disputationis secunda ordinaria \& anniversaria in Academia Regia Hafniensi 7 Nov. 1614, fols. A4r and Br.

\footnotetext{
53 C Bartholin, De studio medico, Copenhagen, 1628 , fols., 1r, 7v-8r; see also idem, Opuscula quatuor singularia, Copenhagen, 1628, where Bartholin includes Paracelsus among the authors consulted and quoted.

${ }^{54}$ Grell, 'Caspar Bartholin', op. cit., note 6 above, pp. 93-4.
} 


\section{Ole Peter Grell}

When Bartholin became professor of theology in 1624 he was succeeded in the medical faculty by his brother-in-law, Ole Worm, who like him was strongly influenced by Rosenkrantz's pre-Pietist Lutheranism. ${ }^{55}$ From his student days, when he had travelled widely in Europe and studied primarily under Jacob Zwinger in Basle, Ole Worm had been deeply interested in Paracelsianism. In 1609 he had intended to study iatrochemistry under Joseph Duchesne and Theodore de Mayerne in Paris, and in 1611 he studied under Johannes Hartmann in Marburg. During his stay in England in 1612, he befriended Theodore de Mayerne, who had by then become royal physician to James I. ${ }^{56}$

Worm's interest in Paracelsianism is also demonstrated by the eagerness with which he tried to obtain information about the Rosicrucians. During 1616 and 1617 he appears to have been undecided, though positively inclined towards the phenomenon, but gradually during 1618 his doubts were growing and by 1620 he rejected Rosicrucianism:

I have seen this little book by "The Brothers" about whether or not The Host is the true Bread; I own it and judge therefrom that the whole Rosicrucian Society, if it is in fact anything at all, is an amalgamation of all sects. Though they declare themselves Lutheran in other tracts, part of their account smacks of fanaticism or anabaptism mixed together with Paracelsus. Accordingly, you should not take the trouble to buy or send it. I thank you for all your help and rely on you if more is published about them in your location. But I am thoroughly convinced that this Society has more or less dissolved itself. ${ }^{57}$

Evidently, Worm was not only worried about the speculative, non-empirical nature of Rosicrucianism, but also the religious heterodoxy it incorporated. As such, it clearly had dangerous implications, especially at a time when doctrinal and ecclesiastical uniformity was the declared goal of the government. ${ }^{58}$ Worm's rejection of this radical manifestation of Paracelsianism, however, should not be interpreted as a wholesale rejection of Paracelsianism as such. Thus in June 1620, Worm, acting on behalf of the King's Chancellor, Christen Friis of Kragerup, requested Peter Severinus's son to publish his father's manuscripts. Worm politely indicated that, if Frederik Sørensen consented, he himself was willing to undertake the editing and publication of them. Furthermore, the Chancellor wanted to borrow some of the manuscripts for personal use. Apparently, Christen Friis, who was also Chancellor of the university, admired Severinus greatly and wanted to spread his fame. ${ }^{59}$ In other words, the eclectic, irenic Paracelsianism introduced by Severinus and Pratensis continued to have strong support within the government and university. ${ }^{60}$

\footnotetext{
55 Andersen, op. cit., note 35 above, pp. 237-40.

56 See Schepelern, op. cit., note 42 above, vol. 1 , nos. 8, 13 and 14, and H D Schepelern, Museum Wormianum, Odense, Wormianum, 1971, pp. 74-85 and 98. Unlike Schepelern, I am convinced that Worm retained his interest in Paracelsianism after he became professor of medicine in 1624 , see below.

${ }^{57}$ Schepelern, op. cit., note 42 above, vol. 1, no. 78 and nos. 20, 25, 38, 44, and 48-9. See also Shackelford, op. cit., note 1 above, p. 273. Worm also appears to have drawn the Rosicrucian phenomenon to the attention of colleagues and friends in Denmark, as can be seen from a letter written by the later professor of theology, Jesper Brochmand, who became a forceful advocate of Lutheran uniformity:
}

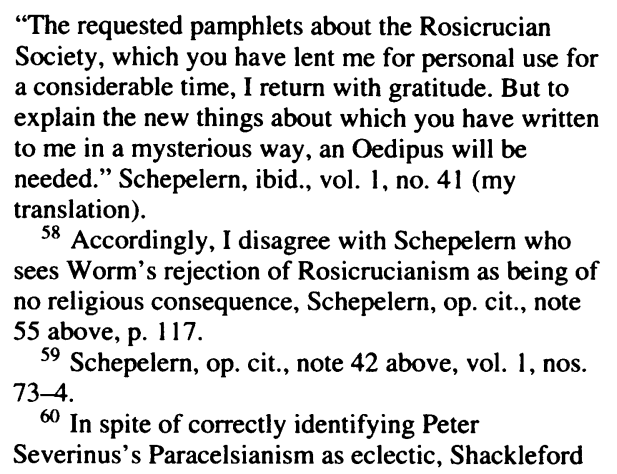




\section{The Reception of Paracelsianism in early modern Lutheran Denmark}

In his inaugural lecture as professor of natural philosophy in April 1621, Worm confirmed his continued belief in the Severinian form of Paracelsianism, arguing that:

God originally gave Adam knowledge of all Nature's secrets, when he asked him to name all creatures. This original wisdom was preserved by the Egyptians, from whom Moses received it. Among his descendants Solomon was especially knowledgeable about Nature; his reputation made the Queen of Sheba visit him and she returned home with the knowledge which has been recorded in hieroglyphs. Later Plato and Aristotle succeeded in collecting and deducing the hidden knowledge and presenting it in a comprehensible form. Although they were heathens, we are permitted to seek the knowledge from them, which God originally gave to Man, and that is why natural philosophy helps us to understand God's omnipotence through his Creation. ${ }^{61}$

Continuing the open-minded and empirical tradition initiated by Severinus, Worm was also critical of parts of his predecessor's natural philosophy and Paracelsian medicine, as can be seen from a publication from 1622, Questiones miscellarum decas. ${ }^{62}$ In prinicple, however, he remained an advocate of a Severinian type of Paracelsianism, as can be seen from a number of the annual disputations he presided over as professor of medicine. Here he not only praised Severinus as the leading iatrochemist of the age, but he also expressed support for Severinus's Christian Platonist doctrine of semina. ${ }^{63}$ As can be seen from his letter of 1648 to his nephew, Rasmus Bartholin, in Leiden his own research continued to incorporate Paracelsian elements:

But I am looking for what Quercetanus [Joseph Duchesne] is describing in his hermetic medicine [Pharmacopoea dogmaticorum restituta pretiosis selectisque hermeticorum floribus abunde illustrata, Paris, 1607], chapter 23; it is either ash or salt, which a certain Pole kept in different bowls, and from which, by heating it a little, he, at pleasure, could produce spiritual plants which possessed lifelike colours, which, when cooled down, once more returned to their salt. ${ }^{64}$

Likewise, Worm continued to encourage students to study iatrochemistry on their peregrinatio academica, and often recommended moderate Paracelsian teachers, such as Guy de la Brosse in Paris, whom he described as an excellent botanist and chemist in a letter to his nephew, Thomas Bartholin, in $1640 .{ }^{65}$

associates later expressions of Paracelsianism in Denmark/Norway with the religious radicalism generally associated with traditional Paracelsianism. Thus he mistakenly sees the case against Lohmann as dictated by the government's and church's hostility towards Paracelsianism per se, rather than worries about religious heterodoxy. This also leads him to see Ole Worm as rejecting Paracelsianism in its totality rather than the religious implications inherent in Rosicrucianism. Likewise his description of Bishop Hans Poulsen Resen as a traditional gnesio-Lutheran does not do justice to a man who was a neo-Platonist and who had befriended heterodox characters such as Giordano Bruno and John Dee as a mature student, while remaining influenced by the pre-Pietist theology of Holger Rosenkrantz, see Shackelford, op. cit., note 1 above, pp. 230-96. For Resen's friendship with Rosenkrantz, see Andersen, op. cit., note 35 above, pp. 133-41, 351-2, and Kornerup, op. cit., note 4 above, vol. 2, pp. 22-4. For Resen's friendship with Giordano Bruno and John Dee, see his Album amicorum, Thott. MS 572, 8, fols 55r and $139 \mathrm{v}$, in the Royal Library, Copenhagen.

61 The Royal Library, Copenhagen, MS Rostgaard 269, 4, nos 28-9 (my translation).

$62 \mathrm{O}$ Worm, Questiones miscellarum decas, Copenhagen, 1622. See also Schepelern, op. cit., note 56 above, pp. 133-4.

${ }^{63} \mathrm{O}$ Worm, Controversiarum medicarum exercitatio II, Copenhagen, 1626; Exercitatio IV, Copenhagen, 1630; Exercitatio XII, Copenhagen, 1644; see also E Hovesen, Lagen Ole Worm, Aarhus Universitetsforlag, 1987, pp. 161, 165 and 185.

${ }^{64}$ Schepelern, op. cit., note 42 above, vol. 3, no. 1575; see also no. 1578 .

65 Ibid., vol. 2, no. 845. 


\section{Ole Peter Grell}

\section{Conclusion}

The legacy of Peter Severinus and Johannes Pratensis, the first generation of "moderate" and eclectic Paracelsians in Denmark, was preserved by Caspar Bartholin and Ole Worm. They inherited a liberal and flexible type of Paracelsianism, which had already demonstrated its ability to co-exist with Galenism. Furthermore, it was a Paracelsianism which from the start proved acceptable to the Philippist leaders of the Lutheran church in Denmark, and which significantly had managed to stay clear of the growing religious controversy of the age-not least thanks to the original irenic and guarded approach of Severinus. This was a lesson not wasted on Severinus's pre-Pietist inheritors. Worm's rejection of Rosicrucianism, in effect, removed the risk of this moderate Paracelsianism becoming embroiled in the drive for uniformity within church and state in Denmark in the second decade of the seventeenth century.

Whether or not Severinus's legacy survived intact in the hands of Caspar Bartholin and Ole Worm may be open to debate; but to try to measure to what extent an already elastic and accommodating type of Paracelsianism became even more flexible is, in my opinion, a futile undertaking. It is undoubtedly most clearly expressed in Pratensis's chosen metaphor of Proteus: it could take many forms, it was difficult to pin-point and was designed to remain elusive. 